\title{
Strategi Peningkatan Kualitas Produk Rokok Kretek "Gagak Hitam" dengan Menggunakan Metode SWOT dan AHP di Perusahaan Rokok Gagak Hitam Kabupaten Bondowoso
}

Strategy to Improve the Quality of "Gagak Hitam" Cigarette Products using the SWOT and AHP Methods in Gagak Hitam Company in Bondowoso Region

\author{
Paramita Andini $^{\# 1}$, Bagus Putu Y.K², Ujang Suryadi ${ }^{3}$, Huda Ahmad Hudori ${ }^{4}$, Fredy Eka A. P \\ \#Jurusan Manajemen Agribisnis, Politeknik Negeri Jember, \\ Jl. Mastrip PO BOX 164 Jember \\ ${ }^{1}$ paramitaandini260592@polije.ac.id
}

\begin{abstract}
ABSTRAK
Penelitian ini bertujuan untuk merumuskan strategi yang tepat dalam meningkatkan kualitas produk rokok kretek Gagak Hitam dan menentukan strategi prioritas yang dapat diterapkan dalam meningkatkan kualitas produk rokok kretek Gagak Hitam. Metode penelitian yang digunakan adalah studi kasus. Analisis yang digunakan adalah Strength, Weakness, Opportunities, Threats (SWOT), dan Analytical Hierarchy Process (AHP). Responden yang digunakan dalam penelitian ini adalah konsumen rokok kretek Gagak Hitam, manajer produksi, manajer personalia dan umum, manajer pengadaan dan perencanaan bahan baku, Disperindag, dan pakar akademik dari Politeknik Negeri Jember. Hasil analisis SWOT didapatkan 7 alternatif strategi yaitu konsistensi racikan, pengembangan pasar, peningkatan SOP, teknologi yang dapat mendukung produktivitas, penambahan kegiatan promosi, pelatihan SDM, dan penambahan bagian Research and Development $(\mathrm{RnD})$. Hasil analisis AHP menghasilkan prioritas strategis yang direkomendasikan untuk perusahaan, yaitu konsistensi racikan.
\end{abstract}

Kata kunci: SWOT, AHP, kualitas produk, Perusahaan Rokok Gagak Hitam, dan Bondowoso

\begin{abstract}
This study aims to formulate the right strategy in improving the quality of "Gagak Hitam" clove cigarette products and to determine the priority strategies that can be applied in improving the quality of "Gagak Hitam" kretek cigarette products. The research method used is a case study. The analysis used is Strength, Weakness, Opportunities, Threats (SWOT), and Analytical Hierarchy Process (AHP). Respondents used for this study were consumers of "Gagak Hitam" kretek cigarettes, production managers, personnel and general managers, managers of procurement and raw material planning, Disperindag, and academic experts from the Jember State Polytechnic. The results of the SWOT analysis obtained 7 alternative strategies, namely consistency of concoctions, market development, increasing SOPs, technology that can support productivity, adding promotional activities, training for $H R$, and adding to the Research and Development (RnD) section. The results of the AHP analysis produce the recommended strategic priority to the company, namely consistency of concoctions.
\end{abstract}

Keywords: SWOT, AHP, product quality, Rokok Gagak Hitam Company, and Bondowoso 


\section{Introduction}

Perusahaan rokok merupakan salah satu industri yang secara terus menerus melakukan proses produksi dengan tujuan untuk menunjukkan eksistensi perusahaan tersebut pada masyarakat. Perusahaan rokok harus mampu bertahan sehingga dapat mengimbangi para pesaingnya. Salah satu cara yang dapat digunakan untuk mengimbangi para pesaing perusahaan rokok adalah dengan menghasilkan produk yang diinginkan konsumen dengan stategi peningkatan kualitas produk rokok sehingga dapat diterima oleh konsumen. Perumusan strategi peningkatan kualitas produk sesuai keinginan konsumen dengan memperhatikan faktor internal dan eksternal. [4]

Produksi rokok nasional tumbuh rata-rata 4,4\% per tahun pada periode 2011-2014 [3]. Kementerian Perindustrian menargetkan pertumbuhan produksi rokok untuk periode 2011-2015 sekitar 3\%-4\%. Target produksi tersebut cenderung rendah karena disesuaikan dengan rencana pembatasan produksi rokok dalam jangka panjang. Industri rokok menghadapi tantangan yang semakin berat, tantangan tersebut yaitu meliputi persaingan semakin ketat, pertumbuhan biaya pokok penjualan lebih tinggi dibanding pertumbuhan pendapatan dalam beberapa tahun terakhir, dan semakin banyak regulasi pemerintah yang membatasi pertumbuhan perindustrian rokok misalnya, cukai, pajak, aturan packaging/pengemasan, iklan/promosi dan larangan merokok di tempat umum.

Perusahaan Rokok Gagak Hitam memproduksi 2 jenis rokok yaitu Sigaret Kretek Tangan (SKT) dan Sigaret Kretek Mesin (SKM). Jenis rokok SKT Gagak Hitam sering terdapat kendala pada proses pembuatannya karena proses produksinya masih dengan cara manual, sehingga sulit menyamakan kualitas lintingan sesuai dengan standar yang ditetapkan perusahaan rokok Gagak Hitam. Segmen produk rokok jenis kretek "Gagak Hitam" merupakan kalangan menengah ke bawah

Beberapa rumusan masalah penelitian ini adalah strategi dan prioritas strategi apakah yang dapat diterapkan untuk meningkatkan kualitas produk. Tujuan penelitian ini adalah untuk merumuskan strategi dan menentukkan prioritas strategi peningkatan kualitas produk rokok di Perusahaan Rokok Gagak Hitam. Target and Output

Sasaran pengabdian masyarakat adalah para Nunc lobortis mattis aliquam faucibus purus in massa tempor. Justo donec enim diam vulputate ut pharetra. Orci eu lobortis elementum nibh tellus molestie. Sodales ut eu sem integer vitae justo eget magna. At ultrices mi tempus imperdiet nulla malesuada pellentesque. Nulla aliquet enim tortor at auctor urna nunc id cursus. Amet nisl purus in mollis nunc sed id. Eu mi bibendum neque egestas congue quisque egestas diam. Ut consequat semper viverra nam. Senectus et netus et malesuada fames ac turpis egestas.

\section{Method}

Penelitian ini dilakukan di Perusahaan Rokok Gagak Hitam Bondowoso, Jawa Timur. Data yang digunakan pada penelitian ini berupa data primer dan skunder. Data primer diperoleh dari wawancara, observasi, dan kuesioner. Sedangkan data skunder diperoleh dari Disperindag Kabupaten Bondowoso, para ahli dibidang kualitas produk rokok, literatur buku, jurnal, dan internet.

Teknik pengambilan sampel pada penelitian ini menggunakan teknik purposive sampling, yaitu teknik pengambilan sampel dengan beberapa pertimbangan [7]. Pertimbangan yang dimaksud adalah secara pengetahuan, kemampuan dan pengalaman yang dimiliki oleh responden. Jumlah responden pada penelitian ini terdiri 5 orang yaitu manajer produksi, Disperindag Kabupaten Bondowoso, konsumen, ahli manajemen kualitas Politeknik Negeri Jember, dan tokoh masyarakat setempat.

Teknik pengolahan dan analisis data menggunakan metode deskriptif kualitatif, SWOT, dan AHP. Analisis SWOT (Strengths, Weakness, Opportunities, Threats) adalah suatu cara untuk mengidentifikasi faktor-faktor secara sistematis untuk merumuskan strategi pada suatu organisasi dengan mempertimbangkan factor internal dan eksternal. Sedangkan analisis AHP (Analytical Hierarchy Process) digunakan untuk menentukkan prioritas strategi yang telah dirumuskan pada alat analisis sebelumnya. 
Penelitian ini diawali dengan mengetahui potensi yang dimiliki permasalahan yang sedang dihadapi oleh perusahaan rokok tersebut. Langkah selanjutnya yaitu mengetahui faktor internal dan ekternal di perusaahan tersebut kemudian merumuskan dengan menggunakan alat analisis SWOT. Tahapan selanjutnya yaitu menentukkan prioritas strategi dengan menggunakan alat analisis AHP. Hasil analisis diharapkan dapat memberikan solusi terbaik unk menyelesaikan masalah yang sedang dihadapi oleh produk Rokok SKT Gagak Hitam tersebut. [5]

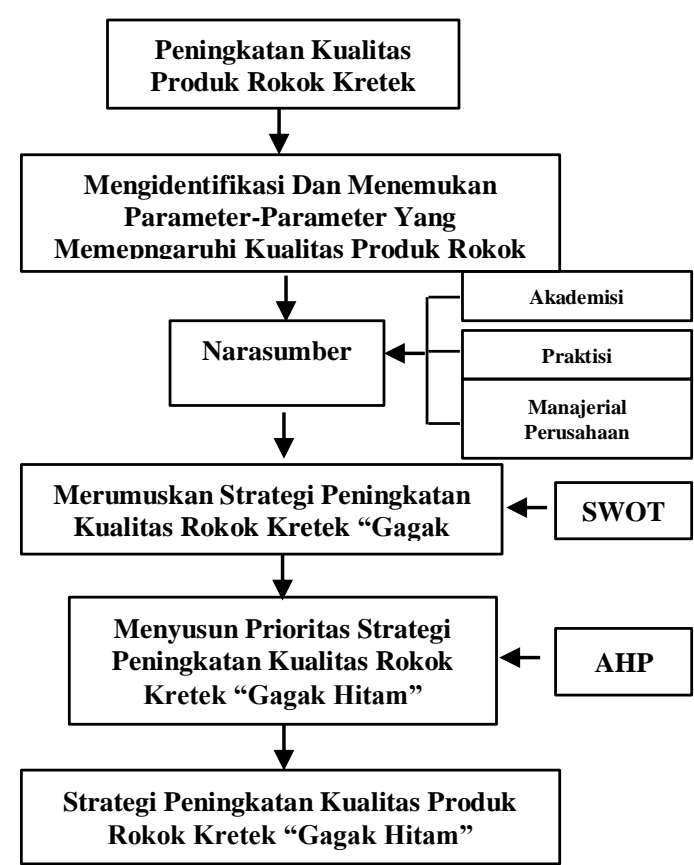

Figure 1. Kerangka Penelitian Peningkatan Kualitas Rokok Kretek "Gagak Hitam"

\section{Discussion}

\subsection{IFE (Identifikasi Faktor Internal)}

Berdasarkan hasil wawancara dan validasi yang telah dilakukan dengan narasumber maka didapatkan 11 indikator dengan rincian 5 indikator kekuatan dan 6 indikator kelemahan produk rokok kretek "Gagak Hitam". indikatorindikator tersebut diuraikan pada Tabel 1. Pada Tabel 1 diketahui bahwa total skor IFE sebesar 2,33 dengan rincian total kekuatan 1,960 dan total kelemahan sebesar 1,07.
Table 1. Matrik IFE Produk Rokok Kretek "Gagak Hitam"

\begin{tabular}{|c|c|c|c|c|}
\hline No & Kekuatan & Bobot & Rating & Skor \\
\hline 1 & $\begin{array}{l}\text { Harga Jual } \\
\text { Produk } \\
\text { Terjangkau }\end{array}$ & 0,10 & 4 & 0,40 \\
\hline 2 & $\begin{array}{l}\text { Bahan baku } \\
\text { melimpah }\end{array}$ & 0,08 & 4 & 0,32 \\
\hline 3 & $\begin{array}{l}\text { Menguasai } \\
\text { pasar lokal } \\
\text { (kabupaten) }\end{array}$ & 0,09 & 2 & 0,18 \\
\hline 4 & $\begin{array}{l}\text { Mudah } \\
\text { memperoleh } \\
\text { produk }\end{array}$ & 0,09 & 2 & 0,18 \\
\hline 5 & $\begin{array}{l}\text { Promosi yang } \\
\text { efektif di pasar } \\
\text { lokal }\end{array}$ & 0.09 & 2 & 0,18 \\
\hline \multirow[t]{2}{*}{ Total } & & 0,45 & & 1,96 \\
\hline & Kelemahan & & & \\
\hline 6 & $\begin{array}{l}\text { Tata kelola } \\
\text { manajemen } \\
\text { yang belum } \\
\text { dikelola } \\
\text { dengan baik }\end{array}$ & 0,08 & 2 & 0,16 \\
\hline 7 & $\begin{array}{l}\text { Kemasan } \\
\text { kurang } \\
\text { menarik }\end{array}$ & 0,08 & 2 & 0,16 \\
\hline 8 & $\begin{array}{l}\text { Kualitas } \\
\text { produk yang } \\
\text { tidak konsisten }\end{array}$ & 0,11 & 1 & 0,11 \\
\hline 9 & $\begin{array}{l}\text { Kapasitas } \\
\text { mesin produksi } \\
\text { terbatas }\end{array}$ & 0,08 & 2 & 0,16 \\
\hline 10 & $\begin{array}{l}\text { Tingkat } \\
\text { Pendidikan } \\
\text { tenaga kerja } \\
\text { minim }\end{array}$ & 0,08 & 1 & 0,08 \\
\hline 11 & $\begin{array}{l}\text { Kurangnya } \\
\text { modal }\end{array}$ & 0,12 & 3 & 0,36 \\
\hline Total & & 0,55 & & 1,07 \\
\hline TOTA & SKOR & 1,00 & & 2,33 \\
\hline
\end{tabular}

Sumber: Data Diolah 2017

Hasil analisis matriks IFE pada Tabel 1 menunjukkan bahwa indikator kekuatan utama Perusahaan Rokok Gagak Hitam berada pada harga jual produk yang murah dengan skor peringkat 4. Harga jual produk murah merupakan faktor internal yang paling baik dibandingkan dengan faktor internal lainnya. Faktor kekuatan harga jual produk terjangkau rokok kretek "Gagak Hitam" merupakan strategi perusahaan yang terus dijalankan hingga saat ini. Segmen pasar yang dituju merupakan ekonomi menengah kebawah yang sensitif dengan harga suatu produk sebagai pertimbangan utama. 
Indikator kelemahan utama Perusahaan Rokok Gagak Hitam yaitu minimnya modal dengan peringkat 3 . Modal yang dibutuhkan cukup besar untuk kegiatan operasionalnya. Modal sendiri yang diterapakan dalam perusahaan tersebut memiliki kelebihan tidak perlu persyaratan yang rumit, tidak bergantung kepada pihak lain, dan tidak perlu mengembalikan modal (bagi hasil). Cara yang dapat ditempuh perusahaan untuk menambah modal yaitu dengan mencari investor bagi perusahaan.

\subsection{Matriks EFE (External Factor Evaluation)}

Berdasarkan hasil wawancara dan validasi yang telah dilakukan dengan narasumber didapatkan 9 indikator, dengan rincian 4 indikator peluang dan 5 indikator ancaman yang dimiliki produk rokok kretek "Gagak Hitam". Hasil analisis matriks EFE, indikator peluang utama yaitu masyarakat sekitar yang gemar merokok dengan peringkat 4 dan pita cukai mahal dengan peringkat 4 untuk ancaman. Rincian indikator-indikator ekternal dapat dilihat pada Tabel 2.

Table 2. Matrik EFE Produk Rokok Kretek "Gagak Hitam"

\begin{tabular}{lllll}
\hline No & Peluang & Bobot & Rating & Skor \\
\hline 1 & $\begin{array}{l}\text { Pemasaran } \\
\text { terbuka luas }\end{array}$ & 0,08 & 3 & 0,24 \\
\hline 2 & $\begin{array}{l}\text { Produsen } \\
\text { Rokok Kretek } \\
\text { Terbaik skala } \\
\text { lokal } \\
\text { (kabupaten) }\end{array}$ & 0,09 & 2 & 0,27 \\
\hline 3 & $\begin{array}{l}\text { Masyarakat } \\
\text { sekitar } \\
\text { perokok aktif }\end{array}$ & 0,12 & 4 & 0,48 \\
\hline 4 & $\begin{array}{l}\text { Peningkatan } \\
\text { skala produksi }\end{array}$ & 0,12 & 3 & 0,36 \\
\hline Total & & $\mathbf{0 , 4 1}$ & \\
\hline & Ancaman & & \\
\hline 5 & $\begin{array}{l}\text { PP } \\
\text { Pembatasan } \\
\text { Industri } \\
\text { Rokok }\end{array}$ & 0,11 & 2 & 0,22 \\
\hline & & & \\
\hline
\end{tabular}

\begin{tabular}{llllc}
\hline 6 & $\begin{array}{l}\text { Kompetitor } \\
\text { Produk } \\
\text { Sejenis }\end{array}$ & 0,12 & 2 & 0,24 \\
\hline 7 & Rokok Ilegal & 0,10 & 2 & 0,20 \\
\hline 8 & $\begin{array}{l}\text { Pita Cukai } \\
\text { Mahal }\end{array}$ & 0,13 & 4 & 0,52 \\
\hline 9 & $\begin{array}{l}\text { Kampanye } \\
\text { Global Anti } \\
\text { Rokok }\end{array}$ & 0,13 & 3 & 0,39 \\
\hline Total & $\mathbf{0 , 5 9}$ & $\mathbf{1 , 5 7}$ \\
\hline TOTAL SKOR & $\mathbf{1 , 0 0}$ & $\mathbf{2 , 8 9}$ \\
\hline \multicolumn{3}{c}{ Sumber: Data Diolah 2017 }
\end{tabular}

Peluang yang paling utama masyarakat sekitar yang merokok, karena kegemaran tersebut peluang yang dimiliki perusahaan rokok gagak hitam dalam memasarkan produknya cukup terbuka. Indikator ancaman utama yang dihadapi perusahaan Rokok Gagak Hitam adalah pita cukai yang mahal dengan peringkat 4. Cukai merupakan pungutan negara yang yang dikenakan terhadap barang-barang tertentu. Pita cukai mahal akan berdampak pada semakin banyaknya rokok ilegal yang beredar di pasaran [6]. Peredaran rokok ilegal tersebut akan merugikan perusahaan rokok yang legal, karena daya beli masyarakat akan menurun terhadap produk perusahaan. dampak lain yang terjadi karena rokok ilegal ini adalah menurunnya pendapatn negara karena rokok yang dikonsumsi masyarakat luas tanpa cukai.

\subsection{Matriks Internal-Ekternal (IE)}

Pada Matriks IE merupakan gabungan matriks IFE dan EFE yang telah diberi bobot dengan peringkat serta telah memiliki skor ratarata tertimbang. Dari nilai bobot tersebut, peringkat dan skor yang telah didapatkan produk rokok kretek "Gagak Hitam" berada pada kuadran ke V. Keterangan posisi perusahaan rokok dapat dilihat pada Gambar 2. 
Matriks IFE yang dibobot

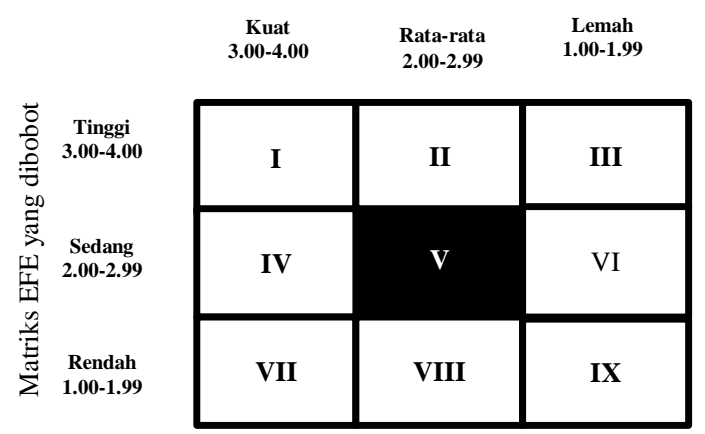

Figure 2. Matriks IE Produk Rokok Kretek “Gagak Hitam"

Hasil analisis dengan menggunakan IFE $(2,50)$ dan EFE $(2,39)$, nilai skor tersebut menempatkan posisi perusahaan berada pada kuadran ke V. Hasil evaluasi tersebut strategi yang dapat dilakukan adalah perusahaan rokok Gagak Hitam berada dalam kondisi Hold dan
Maintain (menjaga dan mempertahankan). Strategi yang dapat dilakukan adalah menerapkan penetrasi pasar dan pengembangan produk. Pengembangan produk merupakan sebuah startegi yang mengupayakan peningkatan penjualan dengan cara memperbaiki atau memodifikasi produk atau jasa saat ini [1]. Cara yang dapat dilakukan untuk memperbaiki produk dan meningkatkan kualitasnya yaitu dengan cara memperhatikan komposisi rokok (racikan) sehingga memiliki rasa yang konsisten, memenuhi kebutuhan teknologi yang dibutuhkan, memperbaiki SOP (Standar Opersioanl Presedur) proses pengolahan rokok, pelatihan tenaga kerja, dan menambah bagian RnD. Upaya perbaikan kualitas produk tersebut merupakan masalah internal perusahaan, untuk menunjang eksternal perusahaan dapat melakukan pengembangan pasar (market development) dan promosi. Matrik SWOT secara lengkap dapat dilihat pada Gambar 3.

Table 3. Hasil Matriks SWOT

\begin{tabular}{l} 
Strenghts \\
\hline Harga jual produk terjangkau \\
Ban baku melimpah \\
Menguasai pasar lokal \\
(Kabupaten) \\
Mudahan memperoleh produk \\
Promosi yag efektif dipasar lokal
\end{tabular}

\section{Weakness}

Tata kelola manajemen yang belum dikelola dengan baik

Kemasan kurang menarik

Kualitas produk yang tidak konsisten

Kapasitas mesin produksi terbatas

Tingkat pendidikan tenaga kerja minim

Kurangnya modal

\begin{tabular}{|c|c|c|}
\hline Opportunity & Strategi SO & Strategi WO \\
\hline $\begin{array}{l}\text { Pemasaran terbuka luas } \\
\text { Produsen rokok kretek terbaik } \\
\text { skala lokal (kabupaten) } \\
\text { Masyarakat sekitar perokok aktif } \\
\text { Peningkatan skala produksi }\end{array}$ & $\begin{array}{l}\text { Konsistensi racikan }(\mathrm{S} 1, \mathrm{~S} 2 \mathrm{Vs} \\
\mathrm{O} 1, \mathrm{O} 2, \mathrm{O} 3) / \mathbf{S O 1} \\
\text { Market development (S3, S4, S5 } \\
\text { Vs O4)/SO2 }\end{array}$ & $\begin{array}{l}\text { SOP perlu ditingkatkan dengan } \\
\text { ditunjang dengan sarana dan } \\
\text { prasarana yang memadai } \\
(\mathrm{O} 1, \mathrm{O} 2, \mathrm{O} 3, \mathrm{O} 4, \mathrm{O} 5, \mathrm{O} 6 \mathrm{Vs} \\
\mathrm{O} 1, \mathrm{O} 2, \mathrm{O} 3, \mathrm{O} 4) / \mathrm{WO}\end{array}$ \\
\hline Threats & Strategi ST & Strategi WT \\
\hline $\begin{array}{l}\text { PP pembatasan industri rokok } \\
\text { Pompetitor produk sejenis } \\
\text { Rokok illegal } \\
\text { Pita cukai mahal } \\
\text { Kampanye global anti rokok }\end{array}$ & $\begin{array}{l}\text { Teknologi yang dapat } \\
\text { mendukung produktivitas SDM } \\
(\mathrm{S} 1, \mathrm{~S} 2, \mathrm{~S} 4 \text { Vs T2, T3)/ST1 } \\
\text { Menambah kegiatan promosi } \\
(\mathrm{S} 3, \mathrm{~S} 5 \mathrm{Vs} \text { T1, T4, T5)/ST2 }\end{array}$ & $\begin{array}{l}\text { Pelatihan bagi SDM (W1, W5, } \\
\text { W6 Vs T1, T4, T5)/WT1 } \\
\text { Menambah bagian unit Research } \\
\text { and Development }(\mathrm{RnD})(\mathrm{W} 2 \text {, } \\
\text { W3, W4 Vs. T2, T4)/WT2 }\end{array}$ \\
\hline
\end{tabular}




\subsection{Penyususunan Hierarki AHP}

Penyususunan hierarki AHP didapatkan dari matriks SWOT dengan didapatkan 7 perumusan strategi yaitu pelatihan, SOP, konsistensi racikan, teknologi, market development, promosi, dan research and development. Hierarki yang digunakan sebagai dasar penyusunan kuesioner AHP dapat dilihat pada Gambar 4.

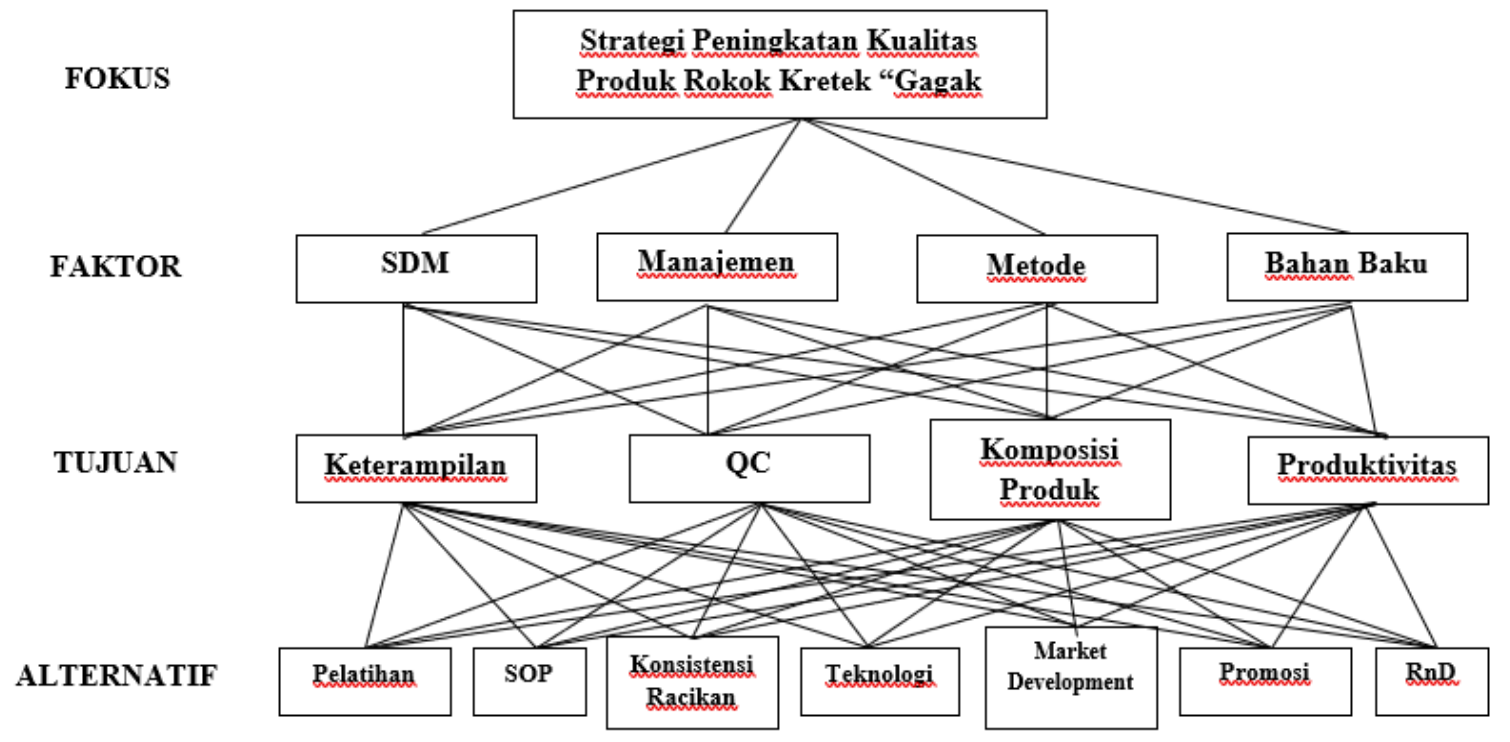

Figure 3. Hierarki Peningkatan Kualitas Produk Rokok Kretek "Gagak Hitam”

3.5. Penentuan Prioritas Strategi Peningkatan Kualitas Produk Rokok Kretek "Gagak Hitam"

Hasil analisis menggunakan AHP, yang menjadi fokus adalah strategi peningkatan kualitas produk rokok kretek Gagak Hitam. Faktor-faktor berpengaruh adalah SDM, manajemen, metode, dan bahan baku. Tujuannya adalah keterampilan pekerja, QC, komposisi produk, dan produktivitas. Alternatif yang ditawarkan yaitu pelatihan, SOP, konsiistensi racikan, teknologi, market development, promosi, research and development $(\mathrm{RnD})$. Hasil analisis AHP dapat dilihat pada Gambar 5.

Combined nslanse -. - $y$ nnchesis with resfec: to Goat Srategi Peningkatan Kualitas Fokok Kretek Gagak Hitam

Konsiss:ensi Racikan

Market Jevelopment

Peningkatan $\mathrm{SO}^{3}$

Teknologi

Promosi

Pelalihan

Menambah Bagian Zesearch and Jevelspment

\section{Overall I consistenoy $=, 02$}

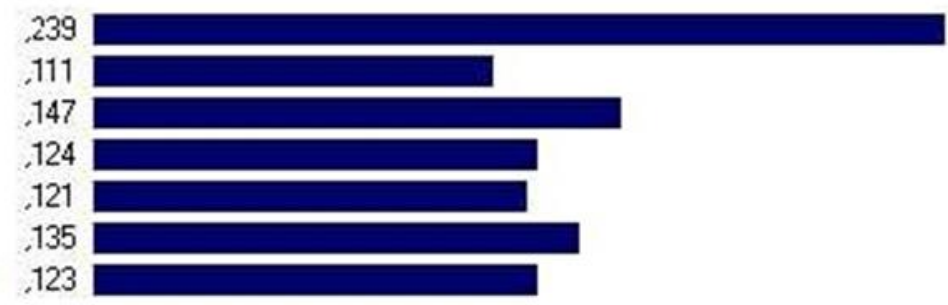

Figure 4. Hasil Analisis AHP

Alternatif Strategi pada Gambar 5 menunjukkan bahwa prioritas pertama yang perlu segera dilakukan oleh perusahaan adalah konsistensi racikan dengan nilai 0,239. Konsistensi racikan dalam meningkatkan strategi peningkatan kualitas produk merupakan faktor yang sangat krusial. Faktor tersebut berhubungan langsung dengan produk dalam hal rasa yang langsung dapat dirasakan oleh konsumen. Rasa rokok kretek "Gagak Hitam" memiliki rasa yang belum konsisten, dikarenakan oleh beberapa faktor yaitu kualitas bahan baku seperti ukuran 
rajangan yang terlalu besar, tembakau yang terlalu lembab, dan bahan lain yang terikut yang dapat mempengaruhi rasa produk rokok kretek "Gagak Hitam", racikan/komposisi produk, dan proses yang kurang tepat (tidak sesuai SOP). Perusahaan rokok Gagak Hitam perlu melakukan beberapa hal untuk memperbaiki kulitas produknya dalam hal konsistensi racikan dengan membuat standar komposisi produk, menjaga stabilitas proses produksi, dan memeriksa bahan antar proses. Rasa suatu produk merupakan hal yang dianggap penting dan diperhatikan oleh konsumen. Konsumen lebih memperhatikan cita rasa menthol, kemudahan memperoleh, kemasan, aroma, kandungan nikotin dan tar, citra atau merk, harga, promosi, dan keapadatan rokok [2]. Konsistensi racikan harus segera diperbaiki, karena jika tidak segera diperbaiki akan mengakibatkan konsumen dapat berpindah merek disebabkan merasa tidak nyaman.

\section{Conclusion}

Berdasarkan matriks Analisis SWOT dan AHP maka diperoleh kesimpulan yaitu, Strategi yang dirumuskan dalam upaya peningkatan kualitas produk rokok adalah memperbaiki kualitas produk dengan memperhatikan komposisi racikan rokok, memenuhi kebutuhan saran dan prasarana, memperbaiki SOP (Standart Operational Presedure) pengolahan rokok, pelatihan tenaga kerja, dan menambah bagian Research and Development (RnD), market development / pengembangan pasar, dan promosi; dan prioritas alternatif strategi peningkatan kualitas produk rokok kretek Gagak Hitam yang diperoleh dari AHP yaitu konsistensi racikan (0,239). Prioritas alternatif strategi selanjutnta yaitu SOP $(0,147)$, pelatihan $(0,135)$, teknologi $(0,124)$ menambah bagian Research and Development $(0,123)$, promosi $(0,121)$, dan market development/pengembangan pasar $(0,111)$.

\section{References}

[1] David, R Fred. 2011. Manajemen Strategis Konsep. Jakarta: Salemba Empat.

[2] Djamaris, A. 2012. Analisis Faktor Perilaku Konsumen Terhadap Atribut Produk Dalam Keputusan Pembelian Food Consumer Product. Business \& Manajemen. Volume 02. No.02. Universitas Bakri, Jakarta, Indonesia.
[3] Industri Bank Mandiri. 2015. Rokok (Cigarette). Jurnal Bank Mandiri. Volume 14, Juli 2015.

[4] Marimin dan Muspita. 2002. Kajian Strategi Peningkatan Kualitas Produk Industri Sayuran Segar (Studi Kasus di Sebuah Agroindustri Sayuran Segar). Jurnal, Vol.13. No.3.

[5] Rangkuti , F. 2015. Teknik Membedah Kasus Bisnis (Analisis SWOT) Edisi Ke-20. Jakarta: PT. Gramedia Pustaka Utama.

[6] Romadhon,dkk. 2016. Evaluasi Pungutan Hasil Cukai Tembakau di Kantor Pelayanan dan Pengawasan Bea dan Cukai Tipe Madya Malang. Jurnal Perpajakan. Vol. 8. No.1.

[7] Sugiyono.2008. Metode Penelitian Kuantitatif, Kualitatif dan RnD. Bandung: Alfabeta. 